Publisher: LPPM STIE Muhammadiyah Bandung

E-ISSN: 2621-5306 P-ISSN: 2541-5255

Vol. 2 No. 3 September - Desember 2018

\title{
PENGARUH PERENCANAAN PAJAK DAN UKURAN PERUSAHAAN TERHADAP MANAJEMEN LABA (Studi Empiris Pada Perusahaan Manufaktur Yang Terdaftar Di Bursa Efek Indonesia Periode 2015-2017)
}

\author{
${ }^{1}$ Dea Savitri Ayu Lestari, ${ }^{2}$ Ia Kurnia, ${ }^{3}$ Yuniati \\ Sekolah Tinggi Ilmu Ekonomi Muhammadiyah Bandung, Indonesia \\ 1,3 yuniati@stiemb.ac.id \\ 2iakurnia_lecturer@stiemb.ac.id
}

\begin{abstract}
ABSTRAK
Penelitian ini dilakukan untuk melihat pengaruh Perencanaan Pajak dan Ukuran Perusahaan terhadap Manajamen Laba (Studi Empiris Pada Perusahaan Manufaktur yang Terdaftar Di Bursa Efek Indonesia). Faktor-faktor yang diuji dalam penelitian ini adalah Perencanaan Pajak dan Ukuran Perusahaan sebagai variabel independen dan Manajemen Laba sebagai variabel dependen.

Metode penelitian yang digunakan adalah metode penelitian deskriptif analisis dan jenis penelitian ini adalah penelitian kuantitatif. Populasi dalam penelitian ini adalah perusahaan manufaktur yang terdaftar di Bursa Efek Indonesia selama periode tahun 2015-2017. Teknik pengambilan sampel dalam penelitian ini menggunakan teknik purposive sampling, sehingga diperoleh jumlah sampel sebanyak 21 perusahaan dengan data akhir berjumlah 63 laporan keuangan. Sumber data dalam penelitian ini adalah data sekunder yang diunduh melalui www.idx.co.id dan website perusahaan masing-masing berupa laporan keuangan tahunan perusahaan selama 3 tahun dalam periode 2015-2017. Teknik analisis data dalam penelitian ini menggunakan analisis regresi linear berganda.

Berdasarkan hasil penelitian dapat disimpulkan bahwa secara simultan perencanaan pajak dan ukuran perusahaan mempunyai pengaruh signifikan terhadap manajemen laba pada perusahaan manufaktur yang terdaftar di Bursa Efek Indonesia periode 2015-2017.

Kata Kunci : Perencanaan Pajak, Ukuran Perusahaan, Manajemen Laba
\end{abstract}

\begin{abstract}
This research was conducted to see the effect of tax planning and company size on earnings management (Empirical Study on Company MAnufacturing Listed In Indonesia Stock Exchange). The factors tested in this study are tax planning and company size as independent variables and earnings management as the dependent variable.

This type of research is descriptive method of analysis and type of research is quantitative research. The population in this study is a manufacturing company listed on the Indonesia Stock Exchange during the period 2015-2017. Sampling technique in this study using purposive sampling technique, so that obtained the number of samples of 21 companies with the final data amounted to
\end{abstract}


63 financial statements. Sources of data in this study are secondary data downloaded through www.idx.co.id and corporate website each in the form of annual financial statements of the company for 3 years in the period 2015 to 2017. Data analysis techniques in this study using multiple linear regression analysis.

The results of this study indicate that simultaneously tax planning and the size of the company have a significant influence on the earings management in manufacturing companies listed on the Indonesia Stock sExchange for the 20152017 period.

Keywords : Tax Planning, Company Size, Profit Management

PENDAHULUAN

Pajak merupakan salah satu sumber pendapatan dalam negeri yang sangat diharapkan eksitensinya dalam menunjang pembelanjaan negara dan pembangunan nasional. Secara umum, suatu negara yang ingin berhasil dalam melaksanakan pembangunannya harus didukung oleh sumber pendanaan yang kuat. Oleh karena itu, pajak dipungut pemerintah yang berdasarkan undang-undang kepada wajib pajak yang merupakan suatu kewajiban yang harus dipenuhi oleh setiap rakyat sebagai bentuk peran serta dalam pembangunan negaranya. Sektor publik memerlukan dana yang sangat besar untuk membiayai pembangunan dan dana ini sebagian besar dari pajak (Bardjo Sugeng, 2011).
Tax is an important factor of State development. Tax Payment is the embodiment of thestate obligation and the role of the Taxpayer to directly and jointly implement the tax obligations for state financing and national development, (Muhamad Iqbal, 2015), dalam (Yuniati \& Yuhanis Ladewi, 2017) dan dalam (Qodariah, Suryadi, \& Yuniati, 2018)

Penerimaan pajak di Indonesia masih kecil sekali, masih banyak ruang yang bisa efisien untuk menambah APBN. Dibawah kepemimpinan Presiden Jokowi harus ada rekor penerimaan pajak tiap tahunnya. Presiden Jokowi yakin hal itu bisa tercapai, apalagi pembayaran pajak telah ditunjang dengan sistem online. Dengan rasio dan tax rasio di Indonesia masih $11 \%$, jadi masih ada ruang dinaikan 


\section{Publisher: LPPM STIE Muhammadiyah Bandung \\ E-ISSN: 2621-5306 P-ISSN: 2541-5255}

Vol. 2 No. 3 September - Desember 2018

baik pribadi, PPn badan ruang itu yang ingin dikerjakan dan perlu diekstensifikasi. Untuk diketahui Nilai (PPN), dan lainnya. (Jokowi, 2016) dalam penelitian (RW, Bagianto \& Yuniati, 2018).

Pajak dapat dilihat dari dua sisi yang berbeda, dari sisi perusahaan pajak merupakan beban yang akan mengurangi laba bersih perusahaan, sedangkan dari sisi pemerintah pajak adalah salah satu sumber penerimaan penting yang akan digunakan untuk membiayai pengeluaran negara baik pengeluaran rutin maupun pengeluaran pembangunan. Namun perbedaan kepentingan antara wajib pajak dengan pemerintah seringkali membuat pelaksanaan pembayaran pajak tidak dapat berjalan dengan semestinya. Perbedaan kepentingan ini membuat persepsi yang salah bahwa dalam pemungutan pajak, aparat pajak atau disebut fiskus akan berusaha untuk mengenakan pajak yang sebesar-besarnya. Sedangkan wajib pajak akan berusaha untuk membayar pajak sekecil-kecilnya (Bardjo Sugeng, 2011).
Dalam suatu perusahaan dimana dari pihak pemegang saham yang memiliki kepentingan tertinggi berkeinginan untuk meningkatkan kekayaannya dan dari pihak manajemen ingin berusaha untuk meningkatkan kesejahteraan bagi perusahaan tersebut. Perselisihan yang terjadi antara pemerintah yang ingin mengambil pajak yang besar dan beberapa perusahaan ini menjadikan manajemen perusahaan berfikir ulang untuk merencanakan pajaknya agar membayar sekecil mungkin sehingga kekayaan perusahaan tidak akan berkurang lebih banyak. Upaya perusahaan untuk meminimalkan pembayaran pajaknya lebih kecil dengan cara merencanakan pajak ini diperbolehkan selama masih berada dalam undang-undang perpajakan yang berlaku di Indonesia. Hampir seluruh kehidupan perseorangan dan perkembangan dunia bisnis dipengaruhi oleh ketentuan perundang-undangan perpajakan. Pengaruh tersebut cukup berarti sehingga para eksekutif komponen pajak merupakan komponen yang perlu mendapatkan perhatian khusus. 
Sementara sebagian yang lain menilai manajemen laba sebagai aktivitas yang lumrah dilakukan dalam menyusun laporan keuangan apalagi jika upaya rekayasa manajerial ini dilakukan dalam ruang lingkup prinsip akuntansi (Sulistyanto, 2014 : 48).

\section{Perencanaan} pajak merupakan langkah awal dalam manajemen pajak. Manajemen pajak itu sendiri merupakan sarana untuk memenuhi kewajiban perpajakan dengan benar, tetapi jumlah pajak yang dibayarkan dapat ditekan seminimal mungkin untuk memperoleh laba dan likuiditas yang diharapkan. Langkah selanjutnya adalah pelaksanaan kewajiban perpajakan (tax implementation) dan pengendalian pajak (tax control). Pada umumnya, perencanaan pajak (tax planning) mengacu kepada proses usaha dan transaksi Wajib Pajak agar utang pajak berada dalam jumlah yang minimal, tetapi masih dalam bingkai peraturan perpajakan (Handri Rori, 2013).

Pengaruh perencanaan pajak dan ukuran perusahaan terhadap efisiensi beban pajak penghasilan antara lain ditandai oleh fenomena yang muncul dari berbagai fenomena di Indonesia, yang disajikan dalam tabel sebagai berikut :

Tabel 1

Rekapitulasi fenomena perencanaan pajak dan ukuran perusahaan terhadap manajemen laba

\begin{tabular}{|c|c|}
\hline Perusahaan & Kasus \\
\hline $\begin{array}{l}\text { CC , 13 Juni } \\
2014 \quad \text { (ES, } \\
\text { Perwakilan } \\
\text { DJP) }\end{array}$ & $\begin{array}{l}\text { Kelompok CC, yakni PT CC } \\
\text { diduga mengakali pajak sehingga } \\
\text { menimbulkan } \\
\text { pembayaran pajak senurangan } \\
\text { 49,24 miliar. }\end{array}$ \\
\hline $\begin{array}{l}\text { (Jumat, } 24 \\
\text { April 2015) } \\
\text { CC } \\
\text { terindikasi } \\
\text { gelapkan } \\
\text { pajak }\end{array}$ & $\begin{array}{l}\text { Wakil rakyat Minahasa Utara } \\
\text { (Minut) mendesak Bupati SS } \\
\text { untuk mencopot izin CC karena } \\
\text { dinilai telah merugikan negara. } \\
\text { Perusahaan tersebut terindikasi } \\
\text { melakukan penggelapan pajak } \\
\text { hingga nyaris Rp.500 juta } \\
\text { setahun. CC harusnya membayar } \\
\text { pajak sekitar Rp.55 juta pada } \\
\text { bulan Oktober } 2014 \text { lalu, namun } \\
\text { pihak perusahaan hanya } \\
\text { membayar pajak sekitar Rp.10-15 } \\
\text { juta per bulan. Artinya ada selisih } \\
\text { sekitar Rp.40 juta setiap bulan } \\
\text { yang tidak dibayar. }\end{array}$ \\
\hline $\begin{array}{lr}\text { X } & \text { GROUP } \\
\text { on } & 19 \\
\text { Februari } & \\
2016 \quad \text { in } \\
\text { Mancanegar } \\
\text { a } \\
\text { (Forum } \\
\text { Pajak) }\end{array}$ & $\begin{array}{l}\text { X Terjerat Kasus Penghindaran } \\
\text { Pajak. Upaya penghindaran pajak } \\
\text { dalam skala besar ini dalam kurun } \\
\text { waktu } 2009 \text { hingga 2014, } \\
\text { demikian dikutip dari sebuah } \\
\text { laporan yang dirilis PE akhir- } \\
\text { akhir ini. }\end{array}$ \\
\hline
\end{tabular}

Sumber : (Hasil Studi Dokumentasi, 2018 )

Kesimpulan dari tabel di atas adalah fenomena yang terjadi pada perusahaan yaitu perencanaan pajak masih dilakukan untuk meminimalkan pembayaran pajaknya sekecil mungkin untuk memperoleh laba yang tinggi. Sementara untuk 


\section{Publisher: LPPM STIE Muhammadiyah Bandung \\ E-ISSN: 2621-5306 P-ISSN: 2541-5255}

Vol. 2 No. 3 September - Desember 2018

menekankan pembayaran pajak seoptimal mungkin, diperlukan adanya suatu perencanaan yang baik terhadap dimensi-dimensi yang mempengaruhinya.

Dalam Penelitian Denny Putri Hapsari, dkk (2016) mengenai pengaruh perencanaan pajak terhadap manajemen laba dengan arus kas operasi sebagai variabel kontrol (studi empiris pada perusahaan manufaktur sub sektor otomotif yang terdaftar di Bursa Efek Indonesia) menggunakan metode deksriptif dengan pendekatan kuantitatif. Hasil penelitian tersebut arus kas operasi mempunyai pengaruh yang kuat terhadap perencanaan pajak dan manajemen laba, sebagai pengendalian dalam melakukan kegiatan operasional pada perusahaan manufaktur sub sektor otomotif. Dalam penelitian Eva Rafika Dewi, Elva Nuraina dan Nik Amah (2017) mengenai pengaruh tax planning dan ukuran perusahaan terhadap manajemen laba (studi empiris pada perusahaan property yang terdaftar di Bursa Efek Indonesia) dengan menggunakan metode analisis statistik deskriptif disertai dengan uji asumsi dasar dan klasik. Hasil penelitian tersebut disimpulkan bahwa tax planning berpengaruh terhadap manajemen laba pada perusahaan property yang terdaftar di Bursa Efek Indonesia. Sementara ukuran perusahaan tidak berpengaruh terhadap manajemen laba pada perusahaan property yang terdaftar di Bursa Efek Indonesia.

Dari uraian di atas dan dari ketidakkonsistenan hasil penelitian sebelumnya, dapat disimpulkan bahwa perencanaan pajak dilakukan perusahaan untuk meminimalkan pembayaran pajak sedangkan besar kecilnya (ukuran) perusahaan akan berpengaruh terhadap besar kecilnya pembayaran pajak yang akan diterima tergantung total aktiva perusahaan. Sementara efisiensi beban pajak penghasilan dilakukan sebagai upaya untuk menekan jumlah kewajiban pajak dengan secara legal yaitu penanganan dan pengelolaan pajak dengan melakukan perencanaan pajak secara efektif. Dari latar belakang di atas serta adanya ketidakkonsistenan hasil penelitian sebelumnya. 
Hal ini dapat dilihat dari dua

\section{KAJIAN LITERATUR DAN HIPOTESIS}

Menurut Drs. Mohammad Zain (2003:67) perencanaan pajak adalah merupakan tindakan penstrukturan yang terkenal dengan konskuensi potensi pajaknya, yang tekanannya kepada pengendalian setiap transaksi yang ada konskuensi pajaknya. Tujuannya adalah bagaimana pengendalian tersebut dapat mengefisiensikan jumlah pajak yang akan ditransfer ke pemerintah, melalui apa yang disebut sebagai penghindaran pajak (tax avoidance) dan bukan penyelundupan pajak (tax evasion) yang merupakan tindak pidana fiskal yang tidak akan ditoleransi.

Menurut Erly Suandy (2011:6) perencanaan pajak adalah langkah awal dalam manajemen pajak. Pada tahap ini dilakukan pengumpulan dan penelitian terhadap peraturan perpajakan agar dapat diseleksi jenis tindakan penghematan pajak yang akan dilakukan. Pada umumnya penekanan perencanaan pajak (tax planning) adalah meminimumkan kewajiban pajak. definisi perencanaan pajak (tax planning) dibawah ini.

1. Tax Planning is the systematic analysis of deferring tax options aimed at the minimization of tax liability in current and future tax periods (Crumbley D. Larry, Friedman Jack P., Anders Susan B., 1994).

2. Tax Planning is arrangements of a person's business andlor private affairs in order to minimize tax liability (Lyons Susan M., 1996).

Menurut

Ompusunggu (2011:3) dalam jurnal Denny, Dwi (2016:56) perencanaan pajak didefinisikan sebagai "Tax Planning adalah suatu kapasitas wajib pajak untuk mengatur aktivitas keuangan yang dapat meminimalkan pembayaran pajak."

Dalam jurnal Priska Febriani Sahilatua, dkk (2013) perencanaan pajak adalah langkah awal dalam manajemen pajak. Perencanaan pajak perlu dilakukan agar pajak yang dibayar proporsional dan sesuai dengan peraturan yang berlaku. 


\section{Publisher: LPPM STIE Muhammadiyah Bandung}

E-ISSN: 2621-5306 P-ISSN: 2541-5255

Vol. 2 No. 3 September - Desember 2018

Perencanaan pajak adalah salah satu contoh memanfaatkan celah peraturan yang memungkinkan perusahaan dengan relatif struktur pajak yang tidak efisien untuk memperbaiki masalahnya sehingga mampu bersaing dengan struktur pajak yang lebih efisien.

Dari beberapa definisi di atas dapat disimpulkan bahwa perencanaan pajak adalah langkah awal dalam manajemen pajak, yang tekanannya kepada pengendalian setiap transaksi yang ada konskuensi pajaknya. Pada tahap ini dilakukan pengumpulan dan penelitian terhadap peraturan perpajakan agar dapat diseleksi jenis tindakan penghematan pajak yang akan dilakukan untuk mengefisiensikan jumlah pajak yang akan dibayar ke pemerintah, melalui penghindaran pajak (tax avoidance) dan bukan penyelundupan pajak (tax evasion) yang merupakan tindak pidana fiskal yang tidak akan ditoleransi. (Drs. Mohammad Zain (2003:67), Erly Suandy (2011:6), Ompusunggu (2011:3) dalam jurnal Denny, Dwi (2016:56)).

Pengukuran Perencanaan Pajak
Menurut Eva Rafika Dewi, dkk (2017: 858), Denny Putri Hapsari, dkk (2016:54), Astutik, Ratna Eka Puji, (2016:10), Ferry Aditama, $\operatorname{dkk}(2014: 44)$ pengukuran pada variabel perencanaan pajak dapat diukur menggunakan laba yaitu laba bersih perusahaan dan laba sebelum pajak pada laporan keuangan tahun berjalan (Wild et al., 2004) dengan rumus tax retentation rate (tingkat retensi pajak).

Ukuran secara umum dapat diartikan sebagai suatu perbandingan besar/kecilnya suatu objek. Dalam jurnal Ayu Sri Mahatma Dewi, dkk (2013) didalam Kamus Besar Bahasa Indonesia, ukuran diartikan sebagai alat untuk mengukur (seperti meter, jangka dan sebagainya), sesuatu yang dipakai untuk menentukan, pendapatan mengukur dan panjangnya (lebarnya, luasnya, besarnya) sesuatu.

Menurut Butar dan Sudarsi (2012) pengertian ukuran perusahaan adalah ukuran perusahaan merupakan nilai yang menunjukkan besar/kecilnya perusahaan.

Menurut Bambang Riyanto (2008:313) pengertian ukuran 
perusahaan adalah sebagai "besar kecilnya perusahaan dilihat dari besarnya nilai equity, nilai penjualan atau nilai aktiva.”

Menurut Machfoedz (1994) dalam Widaryanti (2009) menyatakan Ukuran perusahaan adalah suatu skala dimana dapat diklasifikasikan besar kecil perusahaan menurut berbagai cara (total aktiva, log size, nilai pasar saham, dan lain-lain). Pada dasarnya ukuran perusahaan hanya terbagi dalam 3 kategori yaitu perusahaan besar (large firm), perusahaan menengah (medium-size) dan perusahaan kecil (small firm). Penentuan ukuran perusahaan ini didasarkan kepada total asset perusahaan.

$$
\text { Selanjutnya ukuran }
$$
perusahaan menurut Agus Sartono (2010:249) Perusahaan besar yang sudah well estabilished akan lebih mudah memperoleh modal di pasar modal dibanding dengan perusahaan kecil, karena kemudahan akses tersebut berarti perusahaan besar memiliki fleksibelitas yang lebih besar.
Ukuran perusahaan pada dasarnya adalah pengelompokkan perusahaan kedalam beberapa kelompok di antaranya perusahaan besar, sedang dan kecil. Skala perusahaan merupakan ukuran yang dipakai untuk mencerminkan besar kecilnya perusahaan yang didasarkan kepada total aset perusahaan (Suwito dan Herawaty, 2005).

Jadi dari beberapa pengertian di atas dapat disimpulkan bahwa pengertian ukuran perusahaan adalah suatu skala dimana dapat diklasifikasikan besar kecil perusahaan menurut berbagai cara (total aktiva, log size, nilai pasar saham, dan lain-lain). (jurnal Ayu Sri Mahatma Dewi, dkk (2013) Kamus Besar Bahasa Indonesia, Butar dan Sudarsi (2012), Kieso (2011:192), Bambang Riyanto (2008:313), Machfoedz (1994) dalam Widaryanti (2009), Agus Sartono (2010:249), Suwito dan Herawaty (2005)).

Menurut Eva Rafika Dewi, dkk (2017:859), Prasetyantoko (2008:257), Jogiyanto Hartono (2013:282), Machfoedz (1994) dalam Widaryanti (2009) pengukuran pada variabel ukuran perusahaan dapat 


\section{Publisher: LPPM STIE Muhammadiyah Bandung \\ E-ISSN: 2621-5306 P-ISSN: 2541-5255}

Vol. 2 No. 3 September - Desember 2018

diukur menggunakan total aktiva pada laporan keuangan.

Menurut Davidson, Stickney, dan Weil dalam buku manajemen laba (2014:48) menyatakan bahwa:

"Earnings management is the process of taking deliberate steps within the constrains of generally accepted accounting principles to bring about desired level of reported earnings (Manajemen laba merupakan proses untuk mengambil langkah tertentu yang disengaja dalam batas-batas prinsip akuntansi berterima umum untuk menghasilkan tingkat yang diinginkan dari laba yang dilaporkan).

Menurut

Sulistyanto (2014:216), Denny Putri Hapsari, dkk (2016:60), dan dalam penelitian Yanti Kustiawati (2017:32) variabel manajemen laba dapat diukur menggunakan Model Jones Dimodifikasi dimana model ini banyak digunakan dalam penelitianpenelitian akuntansi karena dinilai merupakan model yang paling baik dalam mendeteksi manajemen.

Gambar 1

Paradigma Penelitian

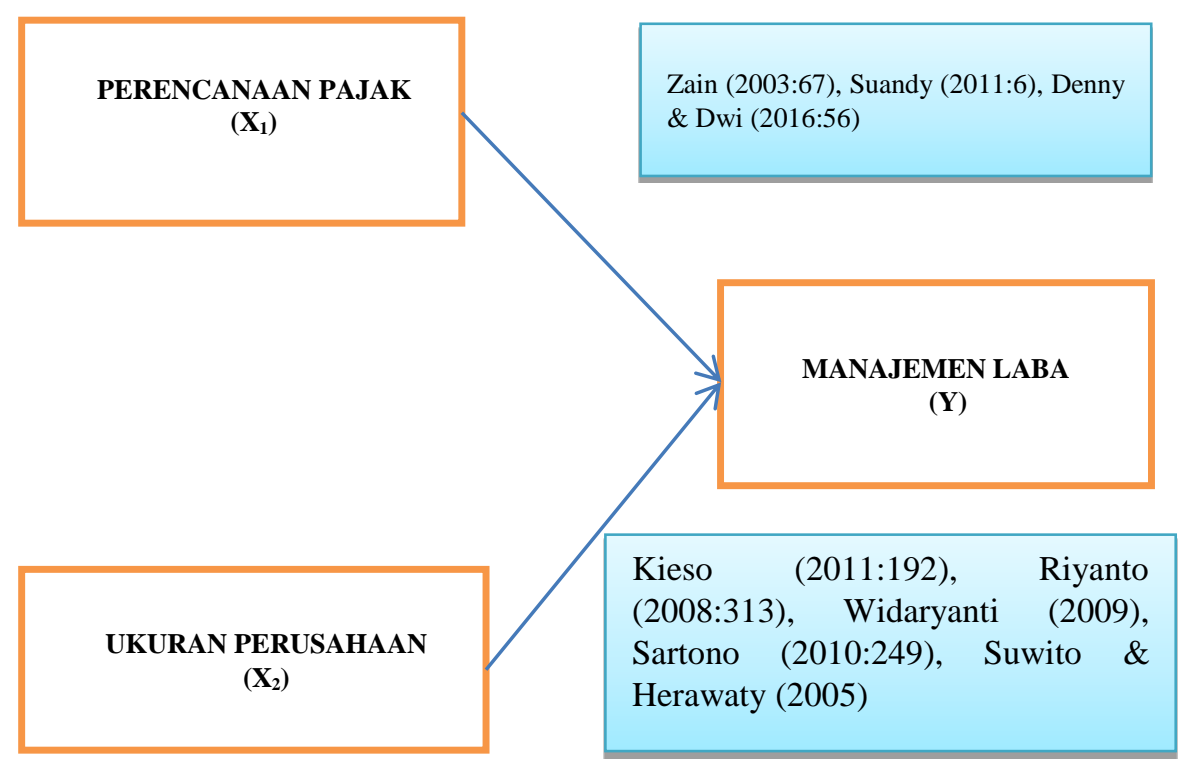




\section{HIPOTESIS}

Berdasarkan identifikasi masalah, tujuan penelitian dan kerangka pemikiran di atas maka diajukan hipotesa sebagai berikut:

$\begin{array}{cc}\mathrm{H}_{1} & \text { : Terdapat pengaruh } \\ & \text { antara Perencanaan } \\ & \text { Pajak terhadap } \\ & \text { Manajemen Laba } \\ & \\ \mathrm{H}_{2} \quad \text { Terdapat pengaruh } & \\ & \text { antara } \\ & \text { Perusahaan } \\ & \text { terhadap } \\ & \text { Manajemen Laba } \\ \mathrm{H}_{3} \quad \text { Terdapat pengaruh } \\ \end{array}$

\section{METODE PENELITIAN}

Metode penelitian yang digunakan dalam penelitian ini merupakan penelitian deskriptif. Penelitian Deskriptif merupakan dasar bagi semua penelitian. Metode penelitian deskriptif berusaha menggambarkan fenomena atau kejadian dari objek yang diteliti berdasarkan fakta-fakta dalam data yang diperoleh dan mengolah data tersebut sehingga dapat ditarik kesimpulan secara umum.

Dalam penelitian ini, objek penelitiannya adalah perencanaan pajak, ukuran perusahaan dan manajemen laba. Penelitian ini menggunakan data sekunder berupa laporan keuangan pada Perusahaan Manufaktur yang terdaftar di Bursa Efek Indonesia periode 2015-2017 yang bersumber dari data laporan keuangan perusahaan yang telah diaudit tahun 2015-2017 yang diperoleh dari situs http://www.idx.co.id.

Dalam penelitian ini populasinya adalah perusahaan yang terdaftar di Bursa Efek Indonesia tahun 2015 sampai 2017 yang diperoleh dari situs http://www.idx.co.id.

Sugiyono (2017 : 137) mengemukakan sampel adalah bagian dari jumlah karakteristik yang dimiliki oleh populasi tersebut. Bila populasi besar, dan peneliti tidak mungkin mempelajari semua yang ada pada populasi, misalnya karena keterbatasan dana, waktu, maka peneliti dapat menggunakan sampel 


\section{Publisher: LPPM STIE Muhammadiyah Bandung \\ E-ISSN: 2621-5306 P-ISSN: 2541-5255}

Vol. 2 No. 3 September - Desember 2018

yang diambil dari populasi itu. Apa yang dipelajari dari sampel itu, kesimpulannya akan dapat diberlakukan untuk populasi. Untuk itu sampel yang diambil dari populasi harus betul-betul representative (mewakili).

"Sampling purposive adalah teknik penentuan sampel dengan pertimbangan tertentu."

Kriteria yang digunakan dalam pemilihan sampel adalah sebagai berikut:

1. Perusahaan Manufaktur yang telah terdaftar di Bursa Efek Indonesia (BEI) dan mempublikasikan laporan keuangan auditan per 31 Desember secara konsisten dan lengkap pada tahun 2015-2017 dan tidak delisting dari Bursa Efek Indonesia (BEI) selama tahun amatan.

2. Data yang diambil merupakan laporan laba rugi (laba akuntansi) perusahaan yang telah diaudit di Bursa Efek Indonesia yang bergerak di bidang Manufaktur.

3. Perusahaan yang mengalami keuntungan dalam laporan keuangan komersial dan laporan keuangan fiskal selama tahun pengamatan.

4. Laporan keuangan yang dinyatakan dalam mata uang rupiah, karena penelitian di lakukan di Indonesia.

5. Laporan keuangan tersebut terdapat informasi yang lengkap terkait dengan semua variabel yang diteliti.

\section{HASIL DAN DISKUSI}

\section{Uji Regresi Linear Berganda}

Tabel 2

\section{Hasil Analisis Regresi}

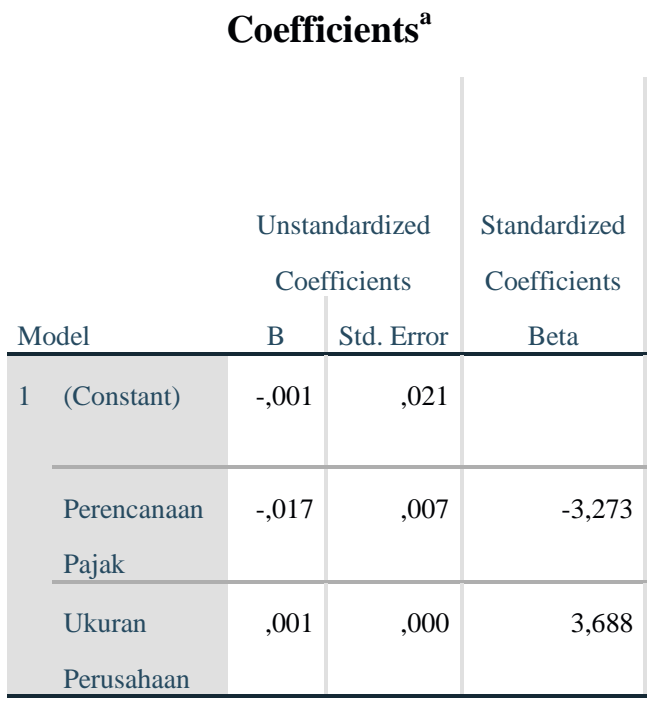

a. Dependent Variable: Manajemen Laba

Sumber: Output SPSS 24, 2018

Dari tabel 4.13 di atas, dapat diperoleh rumus regresi sebagai berikut: 


$$
\mathrm{Y}=-0,001-0,017 \mathrm{X} 1+0,001 \mathrm{X} 2
$$

\section{Berdasarkan persamaan}

regresi di atas, konstanta (a) adalah sebesar -0,001 koefisien perencanaan pajak $\left(\mathrm{X}_{1}\right)$ sebesar - 0,017 dan koefisien ukuran perusahaan $\left(\mathrm{X}_{2}\right)$ sebesar 0,001. Hal ini berarti jika tidak ada perubahan variabel perencanaan pajak dan variabel ukuran perusahaan yang mempengaruhi maka manajemen laba yang terjadi pada perusahaan manufaktur yang terdaftar di Bursa Efek Indonesia periode 2015-2017 adalah sebesar $-0,001$.

\section{Koefisien regresi variabel} Perencanaan Pajak (X1) sebesar 0,017, berarti bahwa setiap peningkatan $1 \%$ maka akan menurunkan variabel Manajemen Laba (Y) sebesar 1,7\%, itu artinya pada perusahaan manufaktur di Bursa Efek Indonesia periode penelitian 2015-2017 melakukan teknik perencanaan pajak dengan cara menurunkan laba atau meminimalkan labanya. Dimana sampel perusahaan dalam penelitian ini menunjukkan hasil nilai total akrual (DTA) yang diolah memiliki nilai total akrual (DTA) negatif (-) yang berarti bahwa perusahaan manufaktur pada periode penelitian melakukan manajemen laba dengan cara meminimalkan labanya (income minimization) atau menurunkan laba (incomedecreasing).

Hal ini sesuai teori (Davidson, dkk (2014:48), Schipper (2014:49), Fisher dan Rosenzweig (2014:49), Sri Sulistyanto (2014:51) bahwa manajemen laba adalah sebagai upaya tindakan manajer untuk menaikkan atau menurunkan laba periode berjalan dari sebuah perusahaan yang dikelolanya dalam batas-batas prinsip akuntansi berterima umum.

Dalam jurnal Suci Prasetyani (2016) bahwa pada tahap menentukan nilai total akrual dapat diketahui bahwa terhadap perusahaan yang memiliki nilai total akrual negatif (-) dan total akrual positif $(+)$. Nilai total akrual negatif (-) menunjukkan bahwa pada tahun berjalan perusahaan diindikasikan melakukan manajemen laba dengan cara income minimization (minimisasi laba), sedangkan nilai total akrual positif (+) menunjukkan 


\section{Publisher: LPPM STIE Muhammadiyah Bandung}

E-ISSN: 2621-5306 P-ISSN: 2541-5255

Vol. 2 No. 3 September - Desember 2018

bahwa pada tahun berjalan a. Predictors: (Constant), Perencanaan Pajak, Ukuran perusahaan diindikasikan melakukan manajemen laba dengan income Perusahaan

b. Dependent Variable: Manajemen Laba Sumber: Output SPSS 24, 2018

maximization (maksimisasi laba).

Dan jika Koefisien regresi variabel ukuran perusahaan (X2) sebesar 0,001, berarti bahwa setiap peningkatan $1 \%$ maka akan meningkatkan variabel Manajemen Laba (Y) sebesar 0,001 pada perusahaan manufaktur di Bursa Efek Indonesia periode penelitian 2015-2017.

\section{Hasil Koefisien Determinasi}

Tabel 3

Koefisien Determinasi Model Summary ${ }^{\mathbf{b}}$

\begin{tabular}{|c|c|c|c|c|}
\hline Model & $\mathrm{R}$ & R Square & $\begin{array}{c}\text { Adjusted R } \\
\text { Square }\end{array}$ & $\begin{array}{l}\text { Std. Error of } \\
\text { the Estimate }\end{array}$ \\
\hline 1 &, $972^{\mathrm{a}}$ & ,944 & ,942 & ,11502 \\
\hline
\end{tabular}

Berdasarkan tabel 4.19 di atas menunjukkan bahwa dari output model summary, diketahui nilai koefisien determinasi (adjusted $R$ square) sebesar 0,944. Besarnya angka koefisien determinasi 0,944 sama dengan $94,4 \%$. Angka tersebut mengandung bahwa perencanaan pajak danukuran perusahaan pada perusahaan manufaktur di Bursa Efek Indonesia periode 2015-2017 sebesar 94,4\%. Sedangkan sisanya $(100 \%-94,4 \%=5,6 \%)$ dipengaruhi oleh variabel lain diluar model regresi ini.

\section{Hasil Uji-t (Parsial)}

\begin{tabular}{clr|r|r|r}
\multicolumn{1}{c}{ Tabel 4} \\
Uji-t (Parsial) \\
Coefficients \\
\end{tabular}

a. Dependent Variable: Manajemen Laba

Sumber: Output SPSS 24, 2018 
Berdasarkan tabel 4 di atas, dapat diperoleh hasil sebagai berikut: 1. Pengujian hipotesis pertama $\left(\mathrm{H}_{1}\right)$

Diketahui nilai signifikan untuk pengaruh $\mathrm{X}_{1}$ terhadap $\mathrm{Y}$ adalah sebesar $0,001<0,05$ dan nilai $t_{\text {hitung }}-3,390<t_{\text {tabel }} 1,671$, sehingga dapat disimpulkan bahwa $\mathrm{H}_{1}$ diterima yang berarti terdapat pengaruh $\mathrm{X}_{1}$ terhadap $\mathrm{Y}$

\section{Tabel 5}

\section{Hasil Uji-t (Parsial) $X_{1}$ TerhadapY}

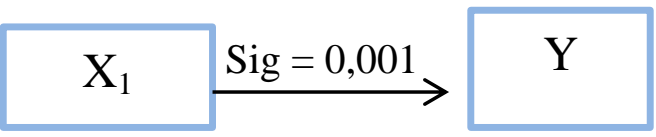

Berdasarkan tabel 5 di atas, diketahui bahwa $X_{1}$ mempunyai tingkat signifikasi sebesar 0,246 lebih besar dari 0,05. Hal ini menunjukkan bahwa variabel perencanaan pajak $\left(\mathrm{X}_{1}\right)$ memiliki berpengaruh terhadap variabel manajemen laba (Y) pada perusahaan manufaktur di Bursa Efek Indonesia periode 2015-2017.
2. Pengujian hipotesis kedua $\left(\mathrm{H}_{2}\right)$

Diketahui nilai sig untuk pengaruh $\mathrm{X}_{2}$ terhadap $\mathrm{Y}$ adalah sebesar 0,366 >0,05 dan nilai $t_{\text {hitung }}$ $0,912<t_{\text {tabel }} 1,671$, sehingga dapat disimpulkan bahwa $\mathrm{H}_{2}$ ditolak yang berarti tidak terdapat pengaruh $\mathrm{X}_{2}$ terhadap Y

\section{Tabel 6}

\section{Hasil Uji-t (Parsial) $\mathbf{X}_{2}$ terhadap $Y$}

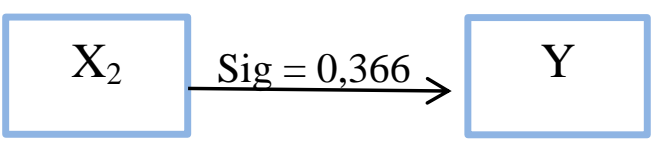

Berdasarkan tabel 6 di atas, diketahui bahwa $X_{2}$ tidak mempunyai tingkat signifikasi sebesar 0,000 lebih besar dari 0,05. Hal ini menunjukkan bahwa variabel ukuran perusahaan $\left(\mathrm{X}_{2}\right)$ tidak berpengaruh terhadap variabel manajemen laba (Y) pada perusahaan manufaktur di Bursa Efek Indonesia periode 2015-2017. 


\section{Hasil Uji F (Simultan)}

Tabel 7

Uji F (Simultan)

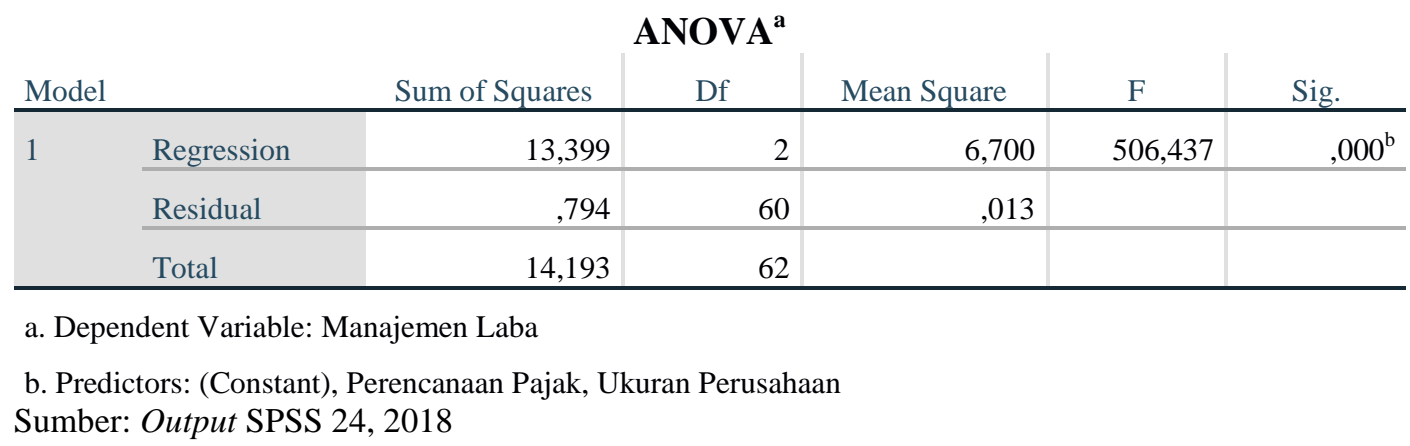

Berdasarkan tabel 4.17 di atas, diketahui nilai signifikansi untuk pengaruh $\mathrm{X}_{1}$ dan $\mathrm{X}_{2}$ secara simultan terhadap $\mathrm{Y}$ adalah sebesar $0,000<0,05$ dan nilai $F_{\text {hitung }}$ $506,437>\mathrm{F}_{\text {tabel }} 3,15$, sehingga dapat disimpulkan bahwa $\mathrm{H}_{3}$ diterima yang berarti terdapat pengaruh $\mathrm{X}_{1}$ dan $\mathrm{X}_{2}$ secara simultan terhadap Y.

Berdasarkan tabel 8 di atas, diketahui bahwa nilai signifikansi untuk pengaruh $\mathrm{X}_{1}$ dan $\mathrm{X}_{2}$ secara simultan terhadap $\mathrm{Y}$ adalah sebesar $0,000<0,05$, sehingga dapat disimpulkan bahwa $\mathrm{H}_{3}$ diterima yang berarti terdapat pengaruh Perencanaan Pajak $\left(\mathrm{X}_{1}\right)$ dan Ukuran Perusahaan $\left(\mathrm{X}_{2}\right)$ secara simultan terhadap Manajemen Laba (Y) pada perusahaan manufaktur di Bursa Efek Indonesia periode 2015-2017.

\section{Hasil Uji Hipotesis}

Dari uji hipotetsis yang telah dilakukan dengan menggunakan SPSS 24, dapat diperoleh hasil sebagai berikut:

\section{Pengaruh Perencanaan Pajak $\left(\mathbf{X}_{1}\right)$ terhadap Manajemen Laba (Y)}

Analisis data telah dilakukan untuk menguji pengaruh secara parsial antara variabel independen yaitu Perencanaan Pajak $\left(\mathrm{X}_{1}\right)$ terhadap variabel dependen yaitu Manajemen Laba (Y). Hasil uji regresi menunjukkan nilai signifikan untuk variabel Perencanaan Pajak sebesar $0,001<0,05$ dan $t_{\text {hitung }}=-3,390 t_{\text {tabel }}$ $=1,671$ yang berarti $-3,390>1,671$ ,sehingga dapat disimpulkan bahwa $\mathrm{H}_{1}$ diterima. Hasil penelitian menunjukkan bahwa terdapat 
pengaruh signifikan antara Perencanaan Pajak $\left(X_{1}\right)$ terhadap variabel yaitu Manajemen Laba (Y) pada perusahaan manufaktur yang terdaftar di Bursa Efek Indonesia.

Hal ini dikarenakan perusahaan melakukan perencanaan pajak bertujuan untuk penghematan pembayaran pajak yang akan dibayarkan kepada pemerintah. Penerapan perencanaan pajak ini harus sesuai dengan ketentuan undang-undang perpajakan yang berlaku saat ini. Manajemen laba merupakan tindakan mengatur laporan keuangan untuk memperoleh keuntungan.

Hasil penelitian menunjukkan bahwa terdapat terdapat adanya pengaruh perencanaan pajak terhadap manajemen laba, artinya perusahaan manufaktur mengindikasikan bahwa perusahaan tersebut melakukan perencanaan pajak sebagai upaya meminimalkan pembayaran pajak yang harus dibayar kepada pemerintah karena dengan total aktiva yang besar dapat berdampak pada laba yang tinggi sehingga perusahaan manufaktur pada saat membayar pajak juga dengan jumlah yang tinggi. Salah satu perencanaan pajak adalah dengan cara mengatur seberapa besar laba yang dilaporkan, sehingga masuk dalam indikasi adanya praktik manajemen laba.

Pengaruh Ukuran Perusahaan $\left(\mathbf{X}_{2}\right)$ terhadap Manajemen Laba (Y)

Analisis data telah dilakukan untuk menguji pengaruh secara parsial antara variabel independen yaitu Ukuran Perusahaan $\left(\mathrm{X}_{2}\right)$ terhadap variabel dependen yaitu Manajemen Laba (Y). Hasil uji regresi menunjukkan nilai signifikan untuk variabel Perencanaan Pajak sebesar $0,366>0,05$ dan $t_{\text {hitung }}=$ $0,912 \mathrm{t}_{\text {tabel }}=1,671$ yang berarti 0,912 $<$ 1,671, sehingga dapat disimpulkan bahwa $\mathrm{H}_{2}$ ditolak. Hasil penelitian menunjukkan bahwa tidak terdapat pengaruh signifikan antara Perencanaan Pajak $\left(\mathrm{X}_{1}\right)$ terhadap variabel yaitu Manajemen Laba (Y) pada perusahaan manufaktur yang terdaftar di Bursa Efek Indonesia.

Hal ini dikarenakan dilihat dari nilai rata-rata total aset yang dimiliki perusahaan manufaktur yang tinggi pada tabel statistik deskriptif menunjukkan nilai sebesar 


\section{Publisher: LPPM STIE Muhammadiyah Bandung \\ E-ISSN: 2621-5306 P-ISSN: 2541-5255}

Vol. 2 No. 3 September - Desember 2018

12,522429, sehingga dapat berdampak pada perolehan laba yang tinggi, selain itu dengan total asset yang tinggi tersebut akan lebih mendapatkan perhatian dari pemerintah maka kemungkinan kecil melakukan perusahaan manufaktur melakukan manajemen laba.

Pengaruh Perencanaan Pajak $\left(\mathbf{X}_{1}\right)$ dan Ukuran Perusahaan $\left(\mathbf{X}_{2}\right)$ terhadap Manajemen Laba (Y)

Analisis data telah dilakukan untuk menguji pengaruh secara parsial antara variabel independen yaitu Perencanaan Pajak $\left(X_{1}\right)$ dan Ukuran Perusahaan $\left(\mathrm{X}_{2}\right)$ terhadap variabel dependen yaitu Manajemen Laba (Y). Hasil uji regresi menunjukkan nilai signifikan $\mathrm{F}$ adalah sebesar 0,000 dan nilai $F_{\text {hitung }}$ $=506,437 \mathrm{~F}_{\text {tabel }}=3,15$, yang berarti $506,437>3,15$, sehingga dapat disimpulkan bahwa $\mathrm{H}_{3}$ diterima dan menyatakan bahwa perencanaan pajak $\left(\mathrm{X}_{1}\right)$ dan ukuran perusahaan $\left(\mathrm{X}_{2}\right)$ berpengaruh secara simultan terhadap variabel yaitu Manajemen Laba (Y) pada perusahaan manufaktur yang terdaftar di Bursa Efek Indonesia.
Hal ini dikarenakan perusahaan manufaktur melakukan perencanaan pajak untuk meminimalkan pembayaran pajak sekecil mungkin yang bertujuan untuk mendapatkan laba yang diinginkan dengan cara mangatur laporan keuangannya, sehingga hal tersebut termasuk dalam indikasi manajemen laba yaitu mengelola laporan keuangan yang bertujuan untuk mendapatkan laba sesuai yang diinginkan baik untuk kepentingan pihak manajemen maupun untuk kesejahteraan karyawan untuk kemajuan perusahaan tersebut.

Sedangkan ukuran perusahaan tercermin pada total aktiva perusahaan tersebut. Hal ini berarti, ukuran perusahaan diduga mampu mempengaruhi besaran pengelolaan laba perusahaan, dimana jika pengelolaan laba efisien maka semakin besar ukuran perusahaan semakin tinggi pengelolaan labanya.

Manajemen Laba merupakan kegiatan yang secara sengaja dilakukan oleh manajemen untuk berbagai kepentingan dan sesuai dengan tujuan manajemen dan perusahaan. Namun yang perlu 
diperhatikan dalam hal melakukan manajemen laba yaitu kebijakankebijakan yang diambil tidak menyimpang dari Prinsip-prinsip Akuntansi yang Berterima Umum (PABU/GAAP).

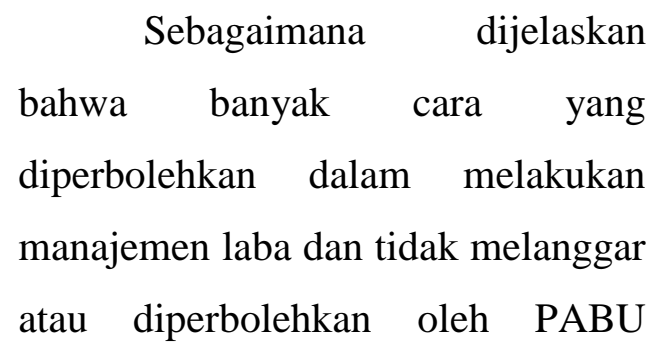
(GAAP.

Maka, dari beberapa
pernyataan di atas walaupun
manajemen laba dilakukan secara
sengaja dan menguntungkan pihak
perusahaan khususnya manajer serta
memberikan informasi yang secara
fakta tidak relevan, namun hal
tersebut diperbolehkan secara
prinsip-prinsip akuntansi,
PABU/GAAP tidak
menyimpang dari standar yang
berlaku)dan sesuai dengan undang-
undang perpajakan yang berlaku
serta tidak melawan hukum.

\section{SIMPULAN}

Penelitian ini dilakukan untuk mengetahui seberapa besar pengaruh perencanaan pajak terhadap manajemen laba, seberapa besar pengaruh ukuran perusahaan terhadap manajemen laba dan seberapa besar pengaruh perencanaan pajak dan ukuran perusahaan terhadap manajemen laba pada Perusahaan Manufaktur yang Terdaftar di Bursa Efek Indonesia Periode 2015-2017, kesimpulan yang dapat diambil sesuai dengan rumusan masalah penelitian adalah sebagai berikut:

1) Berdasarkan hasil penelitian, hampir semua perusahaan yang dijadikan penelitian mengalami fluktuasi nilai perencanaan pajak dari tahun 2015 sampai dengan tahun 2017. Secara parsial Perencanaan Pajak berpengaruh secara signifikan terhadap Manajemen Laba pada perusahaan manufaktur yang terdaftar di Bursa Efek Indonesia. Hal ini berarti semakin sering perusahaan melakukan perencanaan pajak maka semakin tinggi perusahaan melakukan manajemen laba.

2) Berdasarkan hasil penelitian, hampir semua perusahaan yang dijadikan penelitian memiliki fluktuasi nilai ukuran 


\section{Publisher: LPPM STIE Muhammadiyah Bandung \\ E-ISSN: 2621-5306 P-ISSN: 2541-5255}

Vol. 2 No. 3 September - Desember 2018

perusahaan yang baik dari tahun 2015 sampai dengan tahun 2017. Secara parsial Ukuran Perusahaan tidak berpengaruh secara signifikan terhadap Manajemen Laba pada perusahaan manufaktur yang terdaftar di Bursa Efek Indonesia. Hal ini berarti semakin besar ukuran perusahaan maka tidak mempengaruhi perusahaan melakukan manajemen laba.

3) Berdasarkan hasil penelitian, beberapa perusahaan yang dijadikan penelitian diindikasikan melakukan manajemen laba melalui income minimization dari tahun 2015 sampai dengan tahun 2017. Secara simultan bahwa nilai signifikansi untuk pengaruh Perencanaan Pajak dan Ukuran Perusahaan secara simultan terhadap Manajemen Laba adalah sebesar $0,000<0,05$, yang berarti terdapat pengaruh Perencanaan Pajak $\left(\mathrm{X}_{1}\right)$ dan Ukuran Perusahaan $\left(\mathrm{X}_{2}\right)$ secara simultan terhadap Manajemen Laba (Y) pada perusahaan manufaktur di Bursa Efek Indonesia periode 2015-2017. Hal ini berarti semakin sering perusahaan melakukan perencanaan pajak dan semakin besar ukuran perusahaan maka semakin tinggi perusahaan melakukan manajemen laba dengan cara mengelola laporan keuangannya yang bertujuan memperoleh laba yang meningkat serta melakukan manajemen laba.

Berdasarkan data empiris dari indikator hasil rasio dan pembahasan di atas, dapat dikemukakan beberapa saran praktis dan saran peneliti selanjutnya sebagai berikut :

1) Hendaknya perusahaan dalam melaksanakan perencanaan pajak secara lebih baik lagi, melalui penganalisaan informasi yang ada secara teliti, seperti mengikuti dan mengetahui perkembangan peraturan perpajakan terbaru yang berlaku melalui surat edaran yang dikeluarkan Dirjen Pajak, berita pajak, dan majalah atau koran yang berhubungan dengan perpajakan dalam rangka meminimalkan PPH Badan 
perusahaan melalui perencanaan pajak yang baik.

2) Bagi pihak pemerintah menjadi acuan dalam langkah mengevaluasi terhadap peraturan yang telah berlaku mengenai perencanaan pajak yang dilakukan perusahaan manufaktur. Sehingga dengan adanya tahap evaluasi dapat dilakukan langkah strategis dan berkualitas untuk penerapan perencanaan pajak yang sesuai dengan perusahaan manufaktur agar memberi manfaat yang positif dimasa yang akan datang.

Penelitian ini memiliki beberapa keterbatasan yang dapat dijadikan pertimbangan bagi peneliti berikutnya. Adapun keterbatasanketerbatasan dalam penelitian ini adalah peneliti hanya menggambarkan perusahaan pada manufaktur saja sebagai sampel, sehingga hasil dari penelitian ini tidak dapat digeneralisasikan pada jenis perusahaan lain pertambangan, perbankan, transportasi, dll. Hasil penelitian ini tidak dapat mewakili keseluruhan perusahaan yang terdaftar di Bursa Efek Indonesia.

Penelitian ini hanya mencari pengaruh perencanaan pajak dan ukuran perusahaan terhadap manajemen laba tanpa mengikutsertakan faktor lain yang turut mempengaruhi terjadinya manajemen laba. Peneliti hanya melakukan penelitian dalam kurun waktu 3 tahun yaitu tahun 2015 sampai dengan tahun 2017.

\section{DAFTAR PUSTAKA}

Aditama, Ferry \& Anna Purwaningsih. (2014). Pengaruh Perencanaan Pajak Terhadap Manajemen Laba Pada Perusahaan Nonmanufaktur Yang Terdaftar Di Bursa Efek Indonesia. Yogyakarta : ISSN 0852-1875.

Astutik, Ratna Eka Puji \& Titik Mildwati. (2016). Pengaruh Perencanaan Pajak Dan Beban Pajak Tangguhan Terhadap Manajemen Laba. Jurnal Ilmu dan Riset Akuntansi.

Dewi, Ayu Sri Mahatma \& Ary Wirajaya. (2003). Pengaruh Struktur Modal, Profitabilitas Dan Ukuran Perusahaan Pada Nilai Perusahaan. Fakultas Ekonomi Universitas Udayana (Unud) Bali: ISSN:2302-8556.

Dewi, Eva Rafika ; Elva Nuraina ; Nik Amah. (2017). Pengaruh Tax Planning dan Ukuran Perusahaan Terhadap Manajemen Laba (Studi Empiris Pada Perusahaan Property Yang Terdaftar Di Bursa Efek 


\section{Publisher: LPPM STIE Muhammadiyah Bandung \\ E-ISSN: 2621-5306 P-ISSN: 2541-5255}

Vol. 2 No. 3 September - Desember 2018

Indonesia). Madiun: e-ISSN: 2337-9723.

Drs. Mohammad Zain, AK. (2003). Manajemen Perpajakan. Jakarta : Salemba Empat.

Fitriany, Lucy Citra . (2016). Pengaruh Aset Pajak Tangguhan, Beban Pajak Tangguhan Dan Perencanaan Pajak Terhadap Manajemen Laba (Studi Empiris Pada Perusahaan Manufaktur Yang Terdaftar Di BEI Tahun 2011-2013). Pekanbaru: JOM Fekon Vol.3 No.1.

Ghazali, Imam . (2018). Aplikasi Analisis Multivariate Dengan Program SPSS 25 Edisi 9. Semarang: Badan PenerbitUndip.

Gunawan, I Ketut ; Nyoman Ari Surya Darmawan ; I Gusti Ayu Purnamawati. (2015). Pengaruh Ukuran Perusahaan, Profitabilitas, Dan Leverage Terhadap Manajemen Laba Pada Perusahaan Manufaktur Yang Terdaftar Di Bursa Efek Indonesia (BEI). Jurusan Akuntansi Program S1, Volume 03, No.01.

Handayani, RR. Sri \& Agustono Dwi Rachadi. (2009). Pengaruh Ukuran Perusahaan Terhadap Manajemen Laba. Jurnal Bisnis dan Akuntansi.

Hapsari, Denny Putri \& Dwi Manzilah. (2016). Pengaruh Pencanaan Pajak Terhadap Manajemen Laba Dengan Arus Kas Operasi Sebagai Variabel Kontrol. Jurnal Akuntansi.

http://idx.co.id.

http://www.researchgate.net/publication. https://www.sahamok.com

Mangoting, Yenni. (1999). Tax Planning: Sebuah Pengantar Sebagai Alternatif
Meminimalkan Pajak. Jurnal Akuntansi \& Keuangan.

Prasetyani, Suci. (2016). Pengaruh Book

Tax Differences Terhadap Manajemen Laba Pada Perusahaan Manufaktur Sektor Makanan Dan Minuman Yang Terdaftar Di Bursa Efek Indonesia Tahun 2011-2015.

Bandung.

Prof. Dr. Mardiasmo, MBA., Ak. (2016). Perpajakan. Yogyakarta: Andi.

Qodariyah, I., Suryadi, D., \& Yuniati, Y. (2018). Pengaruh Modernisasi Sistem Administrasi Perpajakan Dan Penyuluhan Perpajakan Terhadap Kepatuhan Wajib Pajak Badan . Jurnal Ilmiah MEA (Manajemen, Ekonomi, \& Akuntansi), 2(3), $\quad$ 84-108. https://doi.org/10.31955/mea.v ol2.iss3.pp84-108.

Republik Indonesia, Undang-Undang Perpajakan.

Republik Indonesia, Undang-Undang Nomor 16 Tahun 2009 Tentang Ketentuan Umum Perpajakan.

Rori,Handri. (2013). Analisis Penerapan Tax Planning Atas Pajak Penghasilan Badan. Manado: ISSN 2303-1174 .

RW, Neng Siti, Bagianto, Agus dan Yuniati Yuniati. (2018). "Pengaruh Pemeriksaan Pajak terhadap Kepatuhan Wajib Pajak dan Dampaknya terhadap Efektivitas Penerimaan Pajak Penghasilan Badan". Jurnal Ilmiah (Manajemen, Ekonomi \& Akuntansi). 115-143. ISSN: 2621-5306.

DOI:https://doi.org/10.31955/ji mea.vol2.iss2.ppl 15-143. 
Sahilatua, Priska Febriani \& Naniek Noviari. (2013). Penerapan Perencanaan Pajak Penghasilan Pasal 21 Sebagai Strategi Penghematan Pembayaran Pajak. Bali: ISSN: 2302-8556.

Soemarso S.R. (2004). Akuntansi Suatu Pengantar. Jakarta: Salemba Empat.

Suandy, Erly . (2011). Perencanaan Pajak Edisi 5. Jakarta: Salemba Empat.

Sugeng, Bardjo. (2011). Pengaruh Perencanaan Pajak Terhadap Efisiensi Beban Pajak Penghasilan. Sumatera Utara: Jurnal Riset Akuntansi Dan Bisnis.

Sugiyono. (2017). Metode Penelitian Bisnis Pendekatan Kuantitatif, Kualitatif, dan $R \& D$. Bandung: PT ALFABETA.

Sulistyanto, H. Sri . (2014). Manajamen Laba. Jakarta: Kompas Gramedia.

V. Wiratna Sujarweni. (2015). Metode Penelitian Ekonomi \& Bisnis. Yogyakarta: Pustakabarupress.

Widaryanti. (2009). Analisis Perataan Laba Dan Faktor-Faktor Yang Mempengaruhi Pada Perusahaan Manufaktur Di Bursa Efek Indonesia. Fokus Ekonomi, Vol. 4 No. 2 Desember.

Yuniati (2016). " Perpajakan Teori, Konsep \& Praktik. Dilengkap aplikasi e-spt, e-billing, dan efilling dan soal soal USKP". Bandung: Children Book Multimedia. ISBN 978-60260112-0-6

Yuniati and Yuhanis Ladewi. (2017). "The Influence Of Internal Control On The Effectiveness Of Income Tax Revenue." International
Journal of Economics, Commerce and Management. United Kingdom. http://ijecm.co.uk/. Vol.V, Issue 11, November 2017. ISSN 23480386. 